\title{
RESEARCH REGARDING THE POLLUTION DEGREE FROM ROMANIAN BLACK SEA COAST
}

\author{
MAGDALENA MITITELU ${ }^{1}$, ELENA MOROŞAN ${ }^{1 *}$, SORINEL MARIUS NEACŞU $^{2}$, ELENA \\ IULIANA IONIŢĂ ${ }^{1}$
}

${ }^{I}$ Department of Clinical Laboratory and Food Safety, Faculty of Pharmacy, "Carol Davila” University of Medicine and Pharmacy, Bucharest, Romania

${ }^{2}$ Biomag Association, Câmpina, Romania

*corresponding author: morosan_elena@yahoo.com

Manuscript received: June 2018

\begin{abstract}
This paper presents an analysis of pollution with heavy metals (cadmium, cooper, zinc, lead) and pesticides: lindan, dichlorodiphenyldichloroethylene (DDE), dichlorodiphenyldichloroethane (DDD), dichlorodiphenyltrichloroethane (DDT) in mussels collected from various areas of the Romanian Black Sea coast, to determine the most and least polluted areas for raw material harvesting. The research has taken into account mussel specificity as filtering-organisms, able to retain large quantities of water pollutants from their living area. The concentrations of heavy metals were determined by atomic absorption spectrophotometry (air/acetylene flame) and the concentrations of pesticide were determined by gas chromatography with electron capture detection (ECD). A relatively high degree of pollution was registered in areas A1 and $\mathrm{A} 2$ with high industrial activities due oil refinery or harbour neighbouring, with $\mathrm{Cu}$ concentrations $(112.30 \pm 3.8 \mu \mathrm{g} / \mathrm{L}$ in $\mathrm{A} 1$ and $119.58 \pm 2.3 \mu \mathrm{g} / \mathrm{L}$ in A2) and $\mathrm{Pb}$ concentrations $(21.44 \pm 1.6 \mu \mathrm{g} / \mathrm{L}$ in $\mathrm{A} 1$ and $24.22 \pm 2.8 \mu \mathrm{g} / \mathrm{L}$ in $\mathrm{A} 2)$ exceeding the maximum limits, as is the case of pesticides detected in these areas. Mussels samples harvested from polluted areas also showed elevated heavy metals values and pesticides concentrations. The areas most suitable for mussel sampling are the A3 and $\mathrm{A} 4$ areas, with less industrial activity.
\end{abstract}

\section{Rezumat}

Lucrarea prezintă o analiză a poluării cu metale grele (cadmiu, cupru, zinc, plumb) şi pesticide (lindan, DDE, DDD, DDT) din midiile recoltate din diverse zone de pe litoralul românesc al Mării Negre pentru a determina zonele optime de recoltare a materiei prime, cu gradul cel mai redus de poluare. Am avut în vedere faptul că midiile sunt organisme filtratoare care reţin cantităţi importante din poluanţii apelor în care trăiesc. Concentraţia metalelor grele a fost analizată prin spectometrie de absorbţie atomică cu flacară aer/acetilenă, iar pesticidele au fost determinate prin gaz cromatografie cu detecție cu captură de electroni. Un grad relativ ridicat de poluare s-a remarcat în zonele A1 şi A2 cu activități industiale intense fiind situate în apropierea unei rafinării respectiv unui port, unde s-au înregistrat concentrații crescute de $\mathrm{Cu}(112,30 \pm 3,8 \mu \mathrm{g} / \mathrm{L}$ în $\mathrm{A} 1$ şi $24,22 \pm 2,8 \mu \mathrm{g} / \mathrm{L}$ în A2) și de $\mathrm{Pb}(21,44 \pm 1,6 \mu \mathrm{g} / \mathrm{L}$ în A1 și 24,22 $\pm 2,8 \mu \mathrm{g} / \mathrm{L}$ în $\mathrm{A} 2)$, concentraţii care depășesc limitele maxime admise. De asemenea şi concentraţiile pesticidelor detectate în aceste zone depăşesc limitele maxime admise. Probele de midii recoltate din zonele poluate au prezentat, de asemenea, valori ridicate de metale grele și pesticide. Zonele cele mai potrivite pentru prelevarea de probe de midii sunt zonele A3 și A3, cu mai puţină activitate industrială şi cu un nivel de poluare mai redus.

Keywords: heavy metals, organic pollutants, absorption spectrometer

\section{Introduction}

Heavy metals and organic pollutants enter the marine environment from various, environmental or anthropogenic, sources, in either dissolved or particulate form. Physicochemical and hydrodynamic conditions in transitional and coast areas influence their transport and distribution. Metals in seawater may undergo such reactions as complexation, ion exchange or precipitation, following their accumulation in the sedimentary substrate $[1,2]$.

Increased amounts of heavy metals in the marine environment represent one of the most serious types of pollution. Involuntary intoxications with heavy metals provide a hazardous milieu for developing for a series of pathologic conditions rising important ethics, healthcare and nutritional issues $[17,18]$.

Concentrations of metal ions in the environment (i.e. water and sediment), are measured by: the influx of sewage-contaminated waters; the degree of marine water dilution depending on inflow of mainland waters (tributaries, rainwater); the organic and nutrient load triggering algae blooming, hypoxia, free ion release. Among the most important sources on the Romanian coastline in terms of influx of heavy metals and organic pollutants, the following may be mentioned: the industrial activities (like oil refinery, harbour activities), 
as well as tourism activities, car transportation and shipping activities.

Seawater only retains very small amounts of each element, whereas environmental factors determine their distribution in such a way that a significant amount of such metals accumulates in the bottom sediment, another part influencing the metabolic processes of organisms.

Complex analyses are required because of the close relationship between the biotic and abiotic components of marine ecosystems, for the measurement of heavy metal concentrations in water and sediment as well as in plants and animals.

Concentrations of heavy metals and organochlorine pesticides in marine organisms are important indicators of contaminant impact on marine environment. Due to their high capacity to bio-accumulate various pollutants from the marine environment, mussels are one of the most commonly used bio-indicators to characterise marine contamination $[3,4]$.

\section{Materials and Methods}

For the analysis of heavy metals $(\mathrm{Cd}, \mathrm{Cu}, \mathrm{Zn}, \mathrm{Pb})$ and of organic pollutants (lindane, dichlorodiphenyldichloroethylene (DDE), dichlorodiphenyldichloroethane (DDD), dichlorodiphenyltrichloroethane (DDT)) mussel and water samples were harvested from various areas of the Romanian Black Sea coastline (A1, A2, A3, A4), to determine the optimum area for harvesting of least polluted raw material. The research was undertaken during June - August 2017.

Heavy metals analysis was performed by atomic absorption spectroscopy, using the wet digestion method [5-7]. Mussels collected were thoroughly rinsed, separated from the shells, crushed and dried at $105^{\circ} \mathrm{C}$, and then mortar- powdered and homogenised. Powdered samples (shells and flesh, separately) were mineralised by the wet digestion method (mixture of $66 \% \mathrm{HNO}_{3}$ and $98 \% \mathrm{H}_{2} \mathrm{SO}_{4}$ ): $2 \mathrm{~g}$ of homogenised sample were introduced into the digestion vessel (Velp DK-6 Heating Digester), together with $10 \mathrm{~mL}$ 65\% $\mathrm{HNO}_{3}, 5 \mathrm{~mL} 37 \% \mathrm{HCl}$ and $2 \mathrm{~mL} 35 \% \mathrm{H}_{2} \mathrm{O}_{2}$; then, the mixture was heated gradually (at $150^{\circ} \mathrm{C}$, for $1 \mathrm{~h}$, $200^{\circ} \mathrm{C}$, for 2 hours, $250^{\circ} \mathrm{C}$, for $1 \mathrm{~h}$ and $300^{\circ} \mathrm{C}$, for 2 hours). The solutions were next cooled to room temperature, transferred into a $25 \mathrm{~mL}$ volumetric flask and brought to volume with ultra-distilled water.

Aqueous samples $(500 \mathrm{~mL})$ were filtered using Whatman No. 41 (0.45 mm pore size) filter paper for the estimation of dissolved metal content. The filtrate and the collected water samples $(500 \mathrm{~mL}$ each) were preserved with $2 \mathrm{~mL}$ nitric acid to prevent the precipitation of metals. Both samples were tenfold concentrated on a water bath and subjected to nitric acid digestion using the microwave-assisted technique, setting pressure at 30 bars and power at 700 Watts $[8,9]$.
All used reagents were of analytical reagent grade (Merck). The resultant solutions were analysed with an atomic absorption spectrophotometer SHIMADZU AA 6300 (air/acetylene flame) in order to determine the heavy metals concentration: cadmium $(\lambda=228.8$ $\mathrm{nm})$, cooper $(\lambda=324.7 \mathrm{~nm})$, zinc $(\lambda=213.9 \mathrm{~nm})$ and lead $(\lambda=217 \mathrm{~nm})$. A blank digestion solution was made for comparison. A standard solution for each element under investigation was prepared and used for calibration. Triplicate determinations were performed for each solution. Results are expressed as mean \pm SD (standard deviation) of triplicate samples. Data were statistically evaluated using student test $[5,9]$.

Pesticide residues were extracted from samples with ether and acetone (fresh mussels tissue and shells sample) and then were purified on fluorisil column with a layer of anhydrous $\mathrm{Na}_{2} \mathrm{SO}_{4}$. A total of $10 \mathrm{~g}$ fluorisil or aluminium oxide was packed in a glass column with ether of oil. Pesticides were eluted from the column with ethyl ether/ether of oil in the $20 \mathrm{~mL}$ fraction. The fraction was concentrated in a KudernaDanish apparatus to $1 \mathrm{~mL}$.

The water samples were collected from the surface. Samples were collected in $1 \mathrm{~L}$ glass bottles capped with glass caps than were filtered before analysis. The extraction was performed in 24 hours from the collection of the samples. During this time the samples were kept at $4^{\circ} \mathrm{C}$.

An aliquot of $500 \mathrm{~mL}$ of water was applied through the separation funnel. Afterwards, there were added $25 \mathrm{~mL}$ of hexane. After mixing and layering, the upper hexane layer was washed again with $25 \mathrm{~mL}$ of hexane. The procedure was repeated four times. The extract was transferred to a LABOROTA 4001 rotary evaporator for concentrating to about $20 \mathrm{~mL}$ and then was treated with cooper to remove the sulphur containing compounds with a SONOREX RK 52 ultrasonication bath.

After the samples were concentrated as described above, they were transferred onto a fluorisil column with a layer of anhydrous $\mathrm{Na}_{2} \mathrm{SO}_{4}$ for pesticides detection. A total of $10 \mathrm{~g}$ fluorisil or aluminium oxide was packed in a glass column with hexane. Pesticides were eluted from the column with dichlormethane/ hexane in the $20 \mathrm{~mL}$ fraction. The fraction was concentrated in a KUDERNA-DANISH apparatus for concentrating to $1 \mathrm{~mL}$.

The maximum levels for certain heavy metals and organic pollutants allowed in marine water according to Health Ministry Regulations no 1888/2007 [10] are: cadmium $20 \mu \mathrm{g} / \mathrm{L}$, cooper $100 \mu \mathrm{g} / \mathrm{L}$, zinc $50 \mu \mathrm{g} / \mathrm{L}$, lead $20 \mu \mathrm{g} / \mathrm{L}$, lindan $1 \mu \mathrm{g} / \mathrm{L}$, DDE $1 \mu \mathrm{g} / \mathrm{L}$, DDD 1 $\mu \mathrm{g} / \mathrm{L}$, DDT $1 \mu \mathrm{g} / \mathrm{L}$.

For the analysis of pesticides it was used a FISONS gas chromatograph equipped with an electron capture detection (ECD) and a capillary chromatograph column filled with a mixture of silicone oils (QF-1, OV-11, XE- 
FARMACIA, 2018, Vol. 66, 6

60) on chromosorb WHP. Conditions: a $1 \mu \mathrm{L}$ aliquot of extract was injected; column temperature $200^{\circ} \mathrm{C}$; injector temperature $210^{\circ} \mathrm{C}$; detector temperature $250^{\circ} \mathrm{C}$; carrier gas: nitrogen at a flow rate of $4 \mathrm{~mL} /$ min. Each sample was analysed in triplicate and data were statistically processed by ANOVA. Results were expressed as means \pm SD (standard deviation) [11-13] The maximum levels for certain heavy metals and organic pollutants allowed in marine sediment according

to Health Ministry Regulations no 1888/2007 [10] are: cadmium $20 \mu \mathrm{g} / \mathrm{g}$, cooper $150 \mu \mathrm{g} / \mathrm{g}$, zinc $150 \mu \mathrm{g} / \mathrm{g}$, lead $100 \mu \mathrm{g} / \mathrm{g}$, lindan $1 \mu \mathrm{g} / \mathrm{L}$, DDE $1 \mu \mathrm{g} / \mathrm{L}$, DDD 1 $\mu \mathrm{g} / \mathrm{L}$, DDT $1 \mu \mathrm{g} / \mathrm{L}$.

\section{Results and Discussion}

Seawater concentrations of heavy metals and pesticides are shown in Table I and Table II.

Table I

Seawater concentrations of heavy metals $(\mu \mathrm{g} / \mathrm{L})$

\begin{tabular}{|c|c|c|c|c|}
\hline Area & Cadmium & Cooper & Zinc & Lead \\
\hline A1 & $18.4 \pm 2.6^{*}$ & $112.30 \pm 1.8^{*}$ & $47.14 \pm 2.0^{*}$ & $21.44 \pm 1.6^{*}$ \\
\hline A2 & $18.7 \pm 1.2^{*}$ & $119.58 \pm 2.3^{*}$ & $48.88 \pm 2.1$ & $24.22 \pm 2.8$ \\
\hline A3 & $15.7 \pm 4.6$ & $93.50 \pm 2.5$ & $32.58 \pm 1.6^{*}$ & $14.31 \pm 2.5^{*}$ \\
\hline A4 & $14.34 \pm 1.6^{*}$ & $90.12 \pm 3.2^{*}$ & $35.47 \pm 1.9$ & $13.14 \pm 1.5$ \\
\hline
\end{tabular}

Table II

Seawater concentrations of pesticides $(\mu \mathrm{g} / \mathrm{L})$

\begin{tabular}{|c|c|c|c|c|}
\hline Area & lindan & DDE & DDD & DDT \\
\hline A1 & $1.2 \pm 1.6$ & $0.030 \pm 3.2^{*}$ & - & $0.004 \pm 1.2^{*}$ \\
\hline A2 & $1.4 \pm 1.8^{*}$ & $0.080 \pm 2.1^{*}$ & $0.020 \pm 2.2^{*}$ & $0.009 \pm 3.6$ \\
\hline A3 & $0.7 \pm 2.5$ & $0.050 \pm 2.5$ & - & $0.003 \pm 2.5^{*}$ \\
\hline A4 & $0.5 \pm 2.4^{*}$ & $0.070 \pm 1.7^{*}$ & - & $0.005 \pm 1.4$ \\
\hline
\end{tabular}

$* \mathrm{p}<0.001, \mathrm{DDE}=$ dichlorodiphenyldichloroethylene, $\mathrm{DDD}=$ dichlorodiphenyldichloroethane, $\mathrm{DDT}=$ dichlorodiphenyltrichloroethane

A relatively high degree of pollution was registered in areas A1 and A2 with high industrial activities due an oil refinery or harbour, with $\mathrm{Cu}$ concentrations $(112.30 \pm 3.8 \mu \mathrm{g} / \mathrm{L}$ in $\mathrm{A} 1$ and $119.58 \pm 2.3 \mu \mathrm{g} / \mathrm{L}$ in $\mathrm{A} 2)$ and $\mathrm{Pb}$ concentrations $(21.44 \pm 1.6 \mu \mathrm{g} / \mathrm{L}$ in $\mathrm{A} 1$ and $24.22 \pm 2.8 \mu \mathrm{g} / \mathrm{L}$ in $\mathrm{A} 2$ ) exceeding the maximum limits, as is the case of pesticides detected in these areas, increased concentrations above the permissible limits for lindan $(1.2 \pm 1.6 \mu \mathrm{g} / \mathrm{L}$ in $\mathrm{A} 1$, and $1.4 \pm 1.8$ $\mu \mathrm{g} / \mathrm{L}$ in $\mathrm{A} 2$ ).

Heavy metals and pesticides concentrations in mussel flesh and shell are shown in Table III, Table IV, Table V and Table VI.

Table III

Mussel flesh concentration of heavy metals $(\mu \mathrm{g} / \mathrm{g})$

\begin{tabular}{|c|c|c|c|c|}
\hline Area & Cadmium & Cooper & Zinc & Lead \\
\hline A1 & $19.11 \pm 1.9^{*}$ & $202.36 \pm 3.3^{*}$ & $148.33 \pm 2.4^{*}$ & $101.31 \pm 1.6^{*}$ \\
\hline A2 & $19.79 \pm 1.8^{*}$ & $256.21 \pm 2.5$ & $149.61 \pm 3.3$ & $104.68 \pm 2.8^{*}$ \\
\hline A3 & $17.71 \pm 2.5$ & $138.35 \pm 1.2^{*}$ & $145.82 \pm 3.2^{*}$ & $84.24 \pm 2.9$ \\
\hline A4 & $16.64 \pm 2.1^{*}$ & $141.27 \pm 1.6^{*}$ & $142.29 \pm 3.1^{*}$ & $73.56 \pm 1.6^{*}$ \\
\hline
\end{tabular}

$* \mathrm{p}<0.05$

Table IV

Mussel shell concentration of heavy metals $(\mu \mathrm{g} / \mathrm{g})$

\begin{tabular}{|c|c|c|c|c|}
\hline Area & Cadmium & Cooper & Zinc & Lead \\
\hline A1 & $19.23 \pm 1.6^{*}$ & $185.18 \pm 2.7^{*}$ & $144.86 \pm 2.1^{*}$ & $100.94 \pm 1.9^{*}$ \\
\hline A2 & $19.45 \pm 2.9$ & $196.12 \pm 2.1$ & $148.11 \pm 3.1$ & $102.19 \pm 2.2^{*}$ \\
\hline A3 & $16.19 \pm 1.8^{*}$ & $122.45 \pm 1.9^{*}$ & $137.14 \pm 1.1^{*}$ & $79.10 \pm 2.9$ \\
\hline A4 & $16.31 \pm 2.6$ & $126.59 \pm 1.7^{*}$ & $133.65 \pm 2.4$ & $76.63 \pm 1.5^{*}$ \\
\hline
\end{tabular}

$* \mathrm{p}<0.05$

Mussel samples harvested from polluted areas also showed elevated heavy metals values. Increased accumulation of heavy metals in mussel flesh may be noted as compared to shell accumulation. In the A1 and A2 areas, mussel samples showed accumulations of $\mathrm{Cu}(185.18 \pm 2.7 \mu \mathrm{g} / \mathrm{g}$ in $\mathrm{A} 1$ and $196.12 \pm 2.1 \mu \mathrm{g} / \mathrm{g}$ in A2) and $\mathrm{Pb}(100.94 \pm 1.9 \mu \mathrm{g} / \mathrm{g}$ in $\mathrm{A} 1$, and $102.19 \pm 2.2 \mu \mathrm{g} / \mathrm{g}$ in $\mathrm{A} 2$ ), above the maximum permitted levels. 
Table V

Mussel flesh pesticides concentration $(\mu \mathrm{g} / \mathrm{g})$

\begin{tabular}{|c|c|c|c|c|}
\hline Area & lindan & DDE & DDD & DDT \\
\hline A1 & $1.1 \pm 2.6$ & $0.080 \pm 1.2$ & - & $0.008 \pm 3.1^{*}$ \\
\hline A2 & $1.2 \pm 2.4^{*}$ & $0.090 \pm 1.1^{*}$ & - & $0.009 \pm 2.2^{*}$ \\
\hline A3 & $0.4 \pm 2.8$ & $0.020 \pm 2.1$ & - & $0.002 \pm 2.4$ \\
\hline A4 & $0.2 \pm 1.4^{*}$ & $0.010 \pm 1.9^{*}$ & - & $0.001 \pm 1.8^{*}$ \\
\hline
\end{tabular}

$* \mathrm{p}<0.05, \mathrm{DDE}=$ dichlorodiphenyldichloroethylene, $\mathrm{DDD}=$ dichlorodiphenyldichloroethane, $\mathrm{DDT}=$ dichlorodiphenyltrichloroethane

Regarding pesticides concentration in mussel samples, an accumulation of lindan may be observed above the permissible limits in mussel flesh from contaminated areas due to high industrial activities (A1 and A2).
However, a poor retention of water organic pollutants may also be seen in shells, also accounted for the very low fat content in the shell.

\begin{tabular}{|c|c|c|c|c|}
\hline \multicolumn{5}{|c|}{ Mussel shell pesticides conce } \\
\hline Area & lindan & DDE & DDD & DDT \\
\hline A1 & $0.008 \pm 1.9$ & $0.003 \pm 2.6^{*}$ & - & - \\
\hline A2 & $0.006 \pm 1.5^{*}$ & $0.004 \pm 2.3^{*}$ & - & - \\
\hline A3 & $0.002 \pm 2.1$ & $0.001 \pm 3.4$ & - & - \\
\hline A4 & $0.001 \pm 1.9^{*}$ & $0.001 \pm 1.5^{*}$ & - & - \\
\hline
\end{tabular}

$* \mathrm{p}<0.05, \mathrm{DDE}=$ dichlorodiphenyldichloroethylene, $\mathrm{DDD}=$ dichlorodiphenyldichloroethane, $\mathrm{DDT}=$ dichlorodiphenyltrichloroethane

In conclusion, areas most suitable for mussel sampling are the $\mathrm{A} 3$ and $\mathrm{A} 4$ areas, with less industrial activity [14-16].

\section{Conclusions}

Heavy metals and organic pollutants were assessed in mussels collected from various areas on the Romanian Black Sea coastline (A1, A2, A3 and A4) to determine the optimum harvesting factors of least polluted raw material. It has been taken into account the fact that mussels are filtering-organisms, retaining large quantities of water pollutants.

A relatively high degree of pollution could be noted in A1 and A2 areas with high industrial and harbour activities, where concentrations of $\mathrm{Cu}(112.30 \pm 3.8$ $\mu \mathrm{g} / \mathrm{L}$ in $\mathrm{A} 1$ and $119.58 \pm 2.3 \mu \mathrm{g} / \mathrm{L}$ in $\mathrm{A} 2)$ and $\mathrm{Pb}$ $(21.44 \pm 1.6 \mu \mathrm{g} / \mathrm{L}$ in $\mathrm{A} 1$ and $24.22 \pm 2.8 \mu \mathrm{g} / \mathrm{L}$ in A2) exceed the maximum limits. For pesticides as well, increased levels have been detected in these areas, exceeding limits allowed for lindan $(1.2 \pm 1.6$ $\mu \mathrm{g} / \mathrm{L}$ in $\mathrm{A} 1$ and $1.4 \pm 1.8 \mu \mathrm{g} / \mathrm{L}$ in $\mathrm{A} 2$ areas $)$.

Mussel samples harvested from polluted areas also contained elevated concentrations of heavy metals. A greater accumulation of heavy metals was registered in the flesh rather than in shells. In A1 and A2 areas, mussels samples showed accumulations of $\mathrm{Cu}(185.18 \pm$ $2.7 \mu \mathrm{g} / \mathrm{g}$ in $\mathrm{A} 1$ and $196.12 \pm 2.1 \mu \mathrm{g} / \mathrm{g}$ in $\mathrm{A} 2)$ and $\mathrm{Pb}$ $(100.94 \pm 1.9 \mu \mathrm{g} / \mathrm{g}$ in $\mathrm{A} 1$ and $102.19 \pm 2.2 \mu \mathrm{g} / \mathrm{g}$ in A2), above maximum levels allowed.

Regarding the concentration of pesticides in the assessed mussels samples, an accumulation of lindan above the admitted limits could be observed in mussels flesh, in industrial activities contaminated areas (A1 and A2). However, a poor retention of organic pollutants could be observed in the shells, also accounted for the very low fat content of the shells.
As a conclusion, the A3 and A4 areas have been found to be the most suitable areas for mussel sampling, areas with less industrial activity.

\section{References}

1. Surugiu V, Mustaţă Gh, Hârţăscu M, Contributions to the qualitative and quantitative study of the macrozoobenthos from the Danube - Black Sea Canal. Studii şi Cercetări Ştiinţifice - Seria Biologie, 2004; 9: $75-80$.

2. Ko FC, Chang CW, Cheng JO, Comparative study of Polycyclic Aromatic Hydrocarbons in Coral Tissues and the Ambient Sediments from Kenting National Park, Taiwan. Environ Pollut., 2014; 185: 35-43.

3. Sengör GF, Gün H, Kalafatoğlu H, Determination of the Amino Acid and Chemical Composition of Canned Smoked Mussels (Mytilus galloprovincialis L.), Turk. J Vet Anim Sci., 2008; 32: 1-5.

4. Giuseppa Di B, Russo E, Giacomo D, Heavy Metals and Persistent Organic Pollutants in Marine Organisms from Two Sicilian Protected Areas: Strait of Messina and Cape Peloro Lakes. Curr Org Chem., 2017; 21(5): 387-394.

5. Toiu A, Vlase L, Drăgoi CM, Vodnar D, Oniga I, Phytochemical analysis, antioxidant and antibacterial activities of Hypericum humifusum 1. (Hypericaceae). Farmacia, 2016; 64(5): 663-667.

6. Khansari FE, Khansari MG, Abdollahi M, Heavy metals content of canned tuna fish. Food Chem., 2005; 93: 293-296.

7. Türkmen A, Türkmen M, Tepe Y, Akyurt I, Heavy metals in three commercially valuable fish species from Iskenderun Bay, Northern East Mediterranean Sea, Turkey. Food Chem., 2005; 91: 167-172.

8. Edwards JW, Edyvane KS, Boxall VA, Hamann M, Soole KL, Metal levels in seston and marine fish flesh near industrial and metropolitan centres in South Australia. Marine Pollut Bull., 2001; 42(5): 389-396. 
9. Poulsen AH, Kawaguchi S, Kukkonen JVK, Leppanen MT, Nash SMB, Aqueous uptake and sublethal toxicity of p,p'-DDE in non-feeding larval stages of Antarctic krill (Euphausia superba), Environ Pollut., 2012; 160: 185-191.

10. Order of the Ministry of Health $1888 / 2007$, Order for the approval of the List of organohalogenated and heavy metals, as well as the maximum permissible limits for organohalogenated and heavy metals in water and marine sedimentary substrate. Monitorul Oficial, 2017; 839/07.12.2007 (available in Romanian).

11. Khansari FE, Khansari MG, Abdollahi M, Heavy metals content of canned tuna fish. Food Chem., 2005; 93: 293-296.

12. Mititelu M, Ioniţă AC, Moroşan E, Research regarding integral processing of mussels from Black Sea. Farmacia, 2014; 62(3): 625-632.

13. Stanciu G, Mititelu M, Detection of some pollutants from Black Sea mussels. Environ Engin Manag J., 2004; 3(4): 701-706.

14. Mititelu M, Stanciu G, Guţagă S, Heavy metals detection from some food products. Environ Engin Manag J., 2004; 3(4): 707-711.
15. Nedelescu M, Bălălău D, Baconi D, Jula M, Morar D, Gligor A, Bălălău C, Preliminary assessment of heavy metals content of vegetables grown in industrial areas in Romania. Farmacia, 2015; 63(2): 296-300.

16. Tomy GT, Pleskach K, Oswald T, Halldorson T, Helm PA, Macinnis G, Enatioselective bioaccumulation of hexabromocyclododecane and congener-specific accumulation of brominated diphenyl ethers in an Eastern Canadian Arctic marine food web. Environ Sci Technol., 2008; 42: 3634-3639.

17. Diaconu CC, Drăgoi CM, Bratu OG, Neagu TP, Stoian AP, Cobelschi PC, Nicolae AC, Iancu MA, Hainăroşie R, Stănescu AMA, Socea B, New approaches and perspectives for the pharmacological treatment of arterial hypertension. Farmacia, 2018; 66(3): 408-415.

18. Taerel AE, Rosenberg L, Nicolescu T, Ethics and equity in providing pharmaceutical assistance to the population. Revista Romana de Bioetica, 2010; 8(1): 150-154 